\title{
Whole farm safety net programs: an emerging US farm policy evolution?
}

\section{cambridge.org/raf}

\section{Themed Content: U.S. Farm}

Bill: Policy, Politics, and Potential: Review Article

Cite this article: Zulauf $C$ (2020). Whole farm safety net programs: an emerging US farm policy evolution? Renewable Agriculture and Food Systems 35, 435-438. https://doi.org/ $10.1017 /$ S 1742170519000279

Received: 22 October 2018

Revised: 6 March 2019

Accepted: 18 April 2019

First published online: 20 August 2019

\section{Key words:}

Commodity program; crop insurance; farm bill; policy evolution; whole farm program

Author for correspondence:

Carl Zulauf, E-mail: zulauf.1@osu.edu

\section{Carl Zulauf (iD}

Department of Agricultural, Environmental, and Development Economics, The Ohio State University, 13869 State Highway 231, Nevada, Ohio 44849, USA

\begin{abstract}
The 2018 farm bill is the latest in a history that dates to 1933 . Commodity assistance is the only program in all farm bills, but with evolutionary changes. Current farm commodity programs largely make payments to farms, a stark contrast to the 1930s when they limited supply, put a floor under market price, and dampened price increases via public stocks. Crop insurance, which began as an experimental pilot program in 1938, now has its own farm bill title. Almost all commodity and insurance programs have provided assistance based on a calculation specific to an individual commodity's price and/or yield. However, an evolutionary change to whole farm commodity programs may be in its infant stages. They provide assistance for variation in a farm's aggregate revenue across multiple crops. Whole farm experiments currently exist in both the commodity and crop insurance titles. Analysis of a whole farm commodity program finds that its payments differ by year from actual payments made by current commodity programs and are smaller in total.
\end{abstract}

\section{Whole farm safety net programs: an emerging US farm policy evolution?}

The Agriculture Improvement Act of 2018 (US Congress, 2018) is the latest farm bill in a legislative history dating to 1933 . The only program in all farm bills is commodity assistance, but with significant evolution. Commodity program now largely makes payments to farm, a stark contrast to the initial commodity program that raised prices by putting a floor under price and by limiting supply, and also dampened price increases via public stocks. Almost all commodity and insurance programs provide assistance calculated for an individual commodity. However, an evolutionary design change to whole farm programs may be in its infant stages. Both the historic evolution of commodity programs and this potential new evolutionary step are discussed.

This paper looks at the US farm policy through the perspective of economics. The primary reason is that the US farm policy has consistently revolved around farm income and prices as well as expansion of farm commodity demand (Lehrer, 2020; Winders, 2020). This perspective does not mean other factors are unimportant. Other important factors include political power among policy actors (Hansen, 1991; Coppess, 2018), Congressional rules and procedures (Coppess, 2018), policy trends (Lehrer, 2020; Winders, 2020) and prevailing ideology and culture (Coppess, 2018).

\section{Evolutionary redesign of the farm safety net: a brief history}

US farm policy and its history are explored in many articles and books. Primary sources used by this article listed by date of publication are US Department of Agriculture (USDA), Economic Research Service (ERS) (1984), Tweeten (1989), Orden et al. (1999), Orden and Zulauf (2015), Zulauf and Orden (2016) and Coppess (2018). Electronic copies of all farm bills are available at The National Agricultural Law Center (2019).

The first farm bill, the Agricultural Adjustment Act of 1933, authorized a suite of programs to raise farm prices to address the poverty of farm families and, given the farm sector's importance in the US economy, to facilitate recovery from the Great Depression. The inaugural suite consisted of limits on production or marketing, a loan rate program, and public stocks. The suite came to be known as commodity programs. Production/marketing limits reduced supply and raised prices. Loan rates were set above market prices. Farmers could forfeit the crop used as collateral for a loan to the government rather than selling it at a lower market price, making the loan rate a price floor. The forfeited crop became public stocks, which both dampened price increases and served as a source of food security for end users and consumers.

Congress increased loan rates during World War II to incentivize production for the war effort. After the war, an intense debate began over the level of loan rates and thus the level of farm prices. The debate continued until the mid-1960s, with Congress gradually reducing loan rates. 


\section{….... Per Capita Disposable Personal Income _ - Household Income}

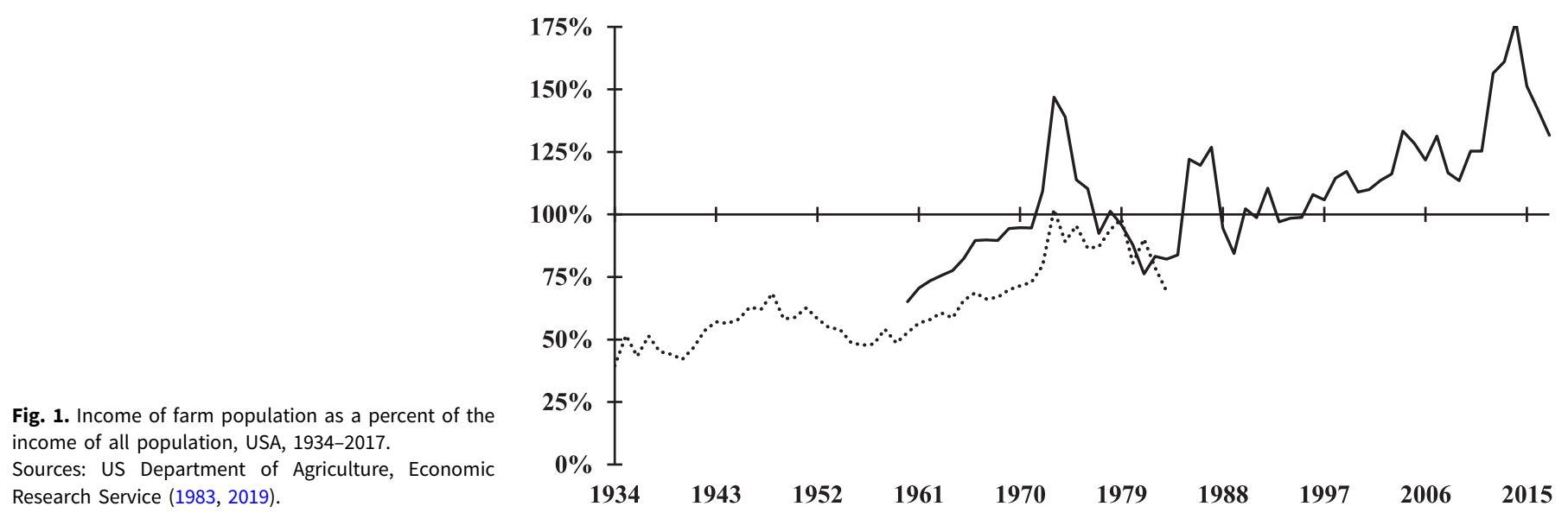

The Agriculture and Consumer Protection Act of 1973 (1973 farm bill), enacted just after the farm prosperity of the 1970s started, authorized deficiency payments to cover the difference if the market price was less than a target price Congress set. It was the first step in replacing price floors with payments. As a result, price flexibility, or range over which price could fluctuate, increased.

Surpluses and low prices reappeared in the early 1980s. In response, the Food Security Act of 1985 (1985 farm bill) reduced loan rates and target prices, and added a deficiency payment option to cotton and rice loans. Known as marketing loans, farmers could opt for a payment in lieu of forfeiting the crop. Payment equaled the difference between a loan rate and a lower market price. Price flexibility increased further as the loan rate price floor was eliminated. Marketing loans were extended to most other program crops by the early 1990s. The price flexibility evolution reached fruition when the Federal Agriculture Improvement and Reform Act of 1996 (1996 farm bill) ended almost all public stock programs, thus removing their dampening effect on price increases.

Concurrent with the price flexibility evolution was an evolution in production flexibility. During the 1960s and 1970s, mandatory production/marketing controls were replaced by voluntary annual acreage set asides for many program crops. Set asides were the eligibility criteria for farm program assistance, thus making loan rates and deficiency payments economic incentives for farmers to set land aside. In the first deficiency payment program in the 1973 farm bill, all acres planted to a program crop were eligible for payments. The 1985 farm bill capped eligible planted acres at a farm's historic base acres for the crop minus a year's set aside acres. To further save money, the Food, Agriculture, Conservation, and Trade Act of 1990 limited eligible acres to $85 \%$ of base acres. To mollify farmers for the reduction in program assistance, any crop except fruits and vegetables could be planted on the $15 \%$ so-called flex acres. The next (1996) farm bill eliminated annual set asides.

The $85 \%$ base acre limit on deficiency payments remains in the 2018 farm bill. Base acres are acres planted during a specified historic period. Use of historic acres means deficiency payments can be received even if no acres are planted to the program crop. Plantings are thus largely guided by the highest net income from the market, not receipt of a program payment.

A third evolution is the addition of crop insurance to the farm safety net. In the mid-1970s, Congress became concerned that the decision to lower loan rates could lead to low yield and low price at the same time. In response, ad hoc disaster assistance was often enacted for prior crop production losses. Then, starting with The Federal Crop Insurance Act of 1980, Congress began to expand the small crop insurance program initiated as an experimental pilot program in 1938. Between 1989 and 2017, insured acres rose from 101 to 312 million and federal insurance premium subsidies grew from $\$ 0.2$ to $\$ 6.2$ billion [USDA, Risk Management Agency (RMA), 2019].

In summary, the price and planting flexibility evolutions materially reduced the role of commodity programs in farm decisions. Markets now largely determine prices and plantings. GDP implicit price deflated outlays for commodity program assistance plus insurance payments to farms' net of the farm-paid premiums have declined from an annual average of $\$ 17.7$ billion in 19891994 to \$10.7 billion in 2013-2017 (calculated using data from the US Congress, Congressional Budget Office, 2018; USDA, FSA, 2018; Federal Reserve Bank of St. Louis, 2019; USDA, RMA, 2019). This calculation starts in 1989 because it is the first year data are available electronically from RMA. Moreover, since the 1930s, the income of the US farm population has moved from below to above the income of the US non-farm population (see Fig. 1). A key, but not only a factor in this change in relative income is the large migration out of farming, particularly between World War II and the early 1970s.

\section{Whole farm safety net programs as a new policy evolution?}

Almost all commodity and insurance programs provided assistance based on a calculation specific to an individual commodity's price and/or yield. However, whole farm commodity and insurance programs are a current farm bill policy experiment. They provide assistance for variation in a farm's aggregate revenue across all program commodities.

The commodity title experiment is ARC-IC (Agriculture Risk Coverage-Individual Farm). First authorized in the 2014 farm bill, it provides assistance when ARC-IC farm revenue is below $86 \%$ of ARC-IC benchmark revenue, both summed for all program crops of a farm. Only $0.8 \%$ of the total 2014 farm bill base acres is in ARC-IC (USDA, FSA, 2019). Reasons for this small footprint are not fully understood, but one is that ARC-IC pays on $65 \%$ of farm base acres. The other commodity program options pay on $85 \%$ of individual crop base acres. The other options are 


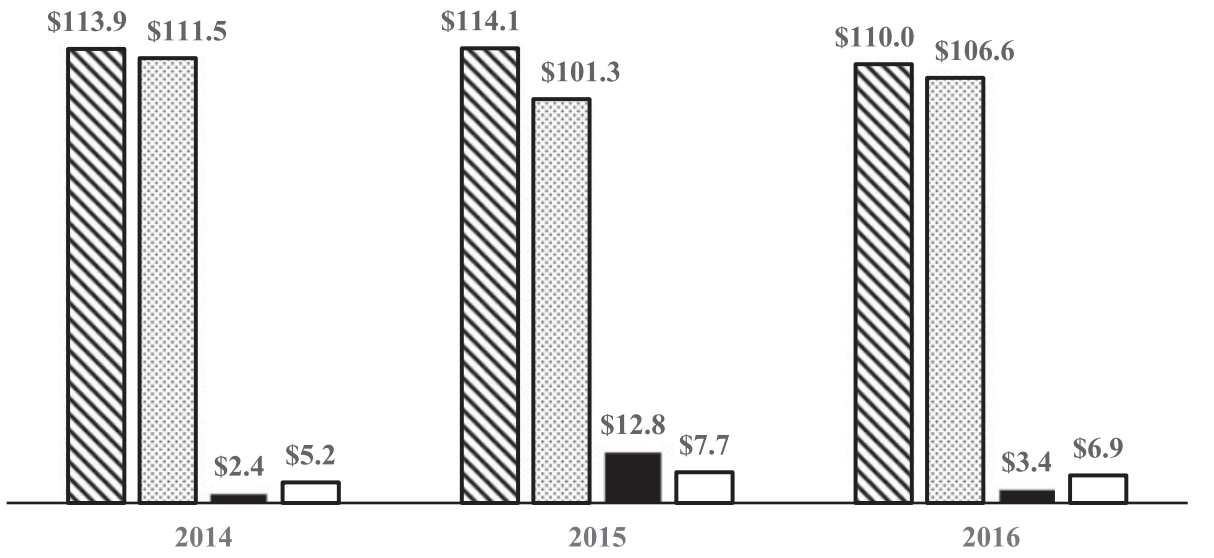

Fig. 2. Whole farm program base revenue, market revenue and payments; and Farm Service Agency reported ARC-CO plus PLC payments, billion \$, eight crops, USA, 2014-2016 market years.

Note: The eight crops are barley, corn, oats, peanuts, rice, sorghum, soybeans and wheat.

Sources: Original calculation using data from US Department of Agriculture (USDA), Farm Service Agency (2019) and USDA, National Agricultural Statistics Services (2019).
ARC-CO, a county individual crop revenue version of ARC, and PLC (Price Loss Coverage), an individual crop price program. The 2018 farm bill reauthorizes all three programs.

ARC-CO and PLC payments are calculated by crop, but made on historic base acres. They do not require planting the crop, and thus are more accurately a payment to a farm, not a crop. Hence, they can be viewed as a potential evolutionary step to a whole farm commodity program.

The insurance title experiment is a Whole Farm Revenue Protection contract. Its footprint is also small, accounting for only $1.7 \%$ of the insured liability in 2017 (USDA, RMA, 2019). However, in the Conference Report that accompanied the 2018 farm bill, its managers state that they 'believe that this policy has the potential to provide vital risk management to producers who are underserved by crop insurance and enhance options for existing policy holders' (US Congress, 2018, electronic page 752 ). A provision is also included in the 2018 farm bill to encourage RMA to make the contract more effective in meeting the needs of farmers. Both of these actions suggest Congress is interested in expanding the footprint of whole farm insurance.

The preceding discussion prompts the policy question, 'Are whole farm programs an emerging farm policy evolution?' To explore further, a whole farm commodity program is created using 2014 farm bill parameters for ARC-CO and PLC, and US national data for the large acreage program crops of barley, corn, oats, peanuts, rice, sorghum, soybeans and wheat. The analysis covers the 2014-2016 crop years, the years for which ARC-CO and PLC payments are available from FSA for all of these crops.

The whole farm program is designed as follows.

(1) whole farm base revenue $=\mathrm{ARC}-\mathrm{CO}$ base revenue plus PLC base revenue summed for eight crops

(2) ARC-CO base revenue for a crop = US ARC-CO base acres times US ARC-CO coverage revenue. The latter equals (86\% times 5-yr Olympic average US yield times 5-yr Olympic average US market year price). An Olympic average removes high and low values.

(3) PLC base revenue for a crop = US PLC base acres times 2014 farm bill reference price times average US base yield for farms electing PLC and updating base yield in the 2014 sign up

(4) whole farm market revenue = US market year price times US production summed for eight crops
(5) whole farm payment $=$ whole farm market revenue minus whole farm base revenue if above 0

Data for the variables are from USDA, FSA (2019) and USDA, National Agricultural Statistics Service (2019). Using the same parameters as the current ARC-CO and PLC programs facilitates comparison of the whole farm $v s$ individual crop calculation of payments.

Whole farm market revenue is less than the whole farm base revenue in each year, resulting in whole farm payments (see Fig. 2). Compared with ARC-CO plus PLC payments reported by FSA, whole farm payments are smaller by $\$ 2.8$ and $\$ 3.5$ billion for 2014 and 2016, but larger by $\$ 5.1$ billion for 2015. Since whole farm revenue is a more encompassing measure of a farm's financial situation, the different payment flows raise the issue of whether ARC-CO and PLC payments match up well with farm sector losses.

Over the 3 years, whole farm payments total $\$ 1.2$ billion (6\%) less than ARC-CO plus PLC payments. This finding is consistent with a conceptual argument for expecting savings. Year-to-year changes in revenue differ across crops. A whole farm program allows high revenue crops to offset at least some of the shortfall of low revenue crops, thus reducing program payments.

\section{Summary observations}

The only program in all US farm bills is commodity assistance, but with substantial evolution. Commodity programs now largely make payments to farmers, a stark contrast to the 1930s when they limited supply, put a floor under market price, and dampened price increases via public stocks. Crop insurance, which started as the experimental pilot program, now has its own farm bill title.

This article argues that an evolution to the whole farm instead of individual commodity design may be in its initial stage. Whole farm experiments exist in both the 2018 farm bill commodity and insurance titles. Moreover, while ARC-CO and PLC calculate the payment on a crop basis, payment is made on historic base acres, not current plantings. Thus, they are more accurately the payment to a farm, not individual crop; and thus may be a potential intermediate step to a whole farm program.

A whole farm commodity program is created using the 2014 farm bill ARC-CO and PLC commodity program parameters. Payments by this whole farm program are estimated to be smaller. This finding is consistent with a conceptual argument that a 
whole farm program should be cheaper. Since revenue changes among crops differ across years, high revenue crops can offset at least some of the shortfall of low revenue crops, thus reducing program payments.

Policy experiments often, probably largely, fail to become an on-going policy feature. Factors that will determine the fate of the whole farm policy experiments include, among others, fit with overall agricultural and national policy trends, strength of supporting $v s$ opposing political coalitions, and fit with the ideological and cultural tone of the times. In the case of the whole farm policy experiments, another key may be whether a consensus arises to either reduce farm safety net spending viewed as excessive or to shift it to non-farm safety net programs. The potential savings whole farm programs offer may thus become a catalyst for moving them beyond policy experiments.

Acknowledgements. The author would like to thank two anonymous reviewers for their comments and suggestions as well as Dr Garrett GraddyLovelace for her encouragement, comments, suggestions and observations.

\section{References}

Coppess J (2018) The Fault Lines of Farm Policy: A Legislative and Political History of the Farm Bill. Lincoln and London: University of Nebraska Press.

Federal Reserve Bank of St. Louis (2019) Federal Reserve Economic Data. Available at https://fred.stlouisfed.org.

Hansen JM (1991) Gaining Access: Congress and the Farm Lobby, 1919-1981. Chicago and London: The University of Chicago Press.

Lehrer N (2020) US farm bills and the 'national interest': an historical research paper. Renewable Agriculture and Food Systems 35, 358-366.

Orden D and Zulauf C (2015) The political economy of the 2014 farm bill. American Journal of Agricultural Economics 97, 1298-1311.

Orden D, Paarlberg R and Roe T (1999) Policy Reform in American Agriculture: Analysis and Prognosis. Chicago: University of Chicago Press.
The National Agricultural Law Center (2019) Copies of all US farm bills. Available at http://nationalaglawcenter.org/farmbills/.

Tweeten L (1989) Farm Policy Analysis. Boulder, Colorado: Westview Press. US Congress (2018) Agriculture Improvement Act of 2018. 115th Congress. Available at https://www.agriculture.senate.gov/imo/media/doc/CRPT-115hrpt 1072.pdf.

US Congress, Congressional Budget Office (2018) CBO's April 2018 Baseline for Farm Programs. Available at https://www.cbo.gov/sites/default/files/ recurringdata/51317-2018-04-usda.pdf.

US Department of Agriculture, Economic Research Service (1983) Economic Indicators of the Farm Sector: Income and Balance Sheet Statistics. ECIFS 3-3. Available at https://babel.hathitrust.org/cgi/pt?id=uc1.32106017429959; view $=1$ up;seq $=3$.

US Department of Agriculture, Economic Research Service (1984) History of Agricultural Price-Support and Adjustment Programs, 1933-84. Agriculture Information Bulletin No. 485. (Report prepared by D.E. Bowers, W.D. Rasmussen, and G.L. Baker). Washington, DC.

US Department of Agriculture, Economic Research Service (2019) Farm household well-being. Available at https://www.ers.usda.gov/data-products/ farm-household-income-and-characteristics/.

US Department of Agriculture, Farm Service Agency (2018) Commodity estimates and books and reports--Table 35. Available at https://www.fsa.usda. gov/about-fsa/budget-and-performance-management/budget/commodityestimates-book-and-reports/index.

US Department of Agriculture, Farm Service Agency (2019) ARC/PLC program, and ARC/PLC program data. Available at https://apps.fas.usda.gov/psdonline/.

US Department of Agriculture, National Agricultural Statistics Service (2019) QuickStats. Available at http://quickstats.nass.usda.gov/.

US Department of Agriculture, Risk Management Agency (2019) Summary of business. Available at http://www.rma.usda.gov/.

Winders B (2020) The global context of the US farm bill in 2018: world markets, instability and policy preferences in agriculture. Renewable Agriculture and Food Systems 35, 367-375.

Zulauf C and Orden D (2016) 80 Years of farm bills: evolutionary reform. Choices. Agricultural and Applied Economics Association. Available at http://www.choicesmagazine.org. 